\title{
A Re-Turn to Place-based Practice of the Arts for Lifelong Learning and Creativity
}

\author{
Diane Butler \\ International Foundation for Dharma Nature Time and Kajian Budaya Doctoral Program \\ Universitas Udayana, Bali, Indonesia \\ dianecarolbutler@gmail.com
}

\begin{abstract}
Every day we face familiar and new situations that require us to make a choice about the direction one wants to take. But, if one does not know where one is coming from or needs to go, too many turns can lead to disorientation. These days, we also face the predicament of choosing whether to make a decision based on the actual reality of one's body-mind 'thinking' or to join the crowd and follow the virtual reality of 'smart' technology. This paper begins by looking at the notion of a 'turn' from the perspective of dance/movement and within the social sciences and humanities. Secondly, it takes up why placebased practice of the arts is increasingly important for people of all ages in the twenty-first century. Finally, it hopes to encourage confidence in prioritizing art-making as a lifelong learning process for the flourishing of cultural creativity.
\end{abstract}

Keywords-arts; place-based practice; lifelong learning; cultural creativity

\section{INTRODUCTION}

This is a slightly revised version of the keynote paper presented at Universitas Negeri Surabaya for the 3rd Social Sciences, Humanities and Education Conference (SoSHEC) convened by the Faculty of Languages and Arts. I felt at ease as I have been involved in the field of dance/movement studies since I was 5 years old; beginning with classes in Dalcroze Eurhythmics - a nonstylized improvisational movement practice to awaken one's kinesthetic awareness and expressive experience of music. Now, I am 58 years old and movement is still the primary language that informs my understanding of the world and also shapes my creativity. Most of my mentors danced from their early childhood to elder years and, hopefully, all of us who attended the SoSHEC 2019 will be active in the arts for many years to come.

In contemplating what I could contribute to the conference, I realized that it was the second of three conferences focused on digital technologies for which I have been invited to deliver a talk. The first time was for the 7th International Seminar on Nusantara Heritage (see Butler [1]) held at University Malaysia Kelantan related to Industry 4.0. The next, in October, was the 1st International Conference on Art Design, Education and Cultural Studies at Universitas Negeri Malang on the Disruptive Era. This thematic trend is clearly calling for educators to give more attention to what has been termed the 'digital turn'. So, for this forum, I decided to share some ideas about A Re-Turn to Place-based Practice of the Arts for Lifelong Learning and Creativity.

First, I will look at the notion of a 'turn' from the perspective of dance/movement and within the social sciences and humanities. Secondly, why place-based practice of the arts is increasingly important for people of all ages in the twenty-first century. Finally, I hope to encourage confidence in prioritizing art-making as a lifelong learning process for the flourishing of cultural creativity.

\section{WHICH 'TURN’ TO TAKE? WISE WORDS FROM A NINETEENTH CENTURY INDONESIAN POET}

Dancing always involves different types of turns. For instance, a turn of the foot to the right or to the left can lead the whole body into a new spatial pathway. The whole body or a segment such as the torso, a hand, the head or eyes can also take a turn upward, downward or sideways; or to the front or to the back. A turn inward can guide the senses to the internal space of the body and a turn outward to the surroundings; while spiraling can bring about a physical experience of 360-degree space. These types of turns, among others, also occur in the movement of our daily life activities.

Theorizing in sub-disciplines within the social sciences and humanities often names a shift in emphasis as a 'turn'; such as when scholars become aware of a social change or begin to address an unrecognized segment of society or reorient analytical processes. While I was reading potential texts for the literature review section of my dissertation [2] about religiosity in art, I encountered discourses on the linguistic turn, the cultural turn, the historical turn, the sensory turn, the practice turn, the reflexive turn, the participatory turn, the spatial turn, the temporal turn, the somatic turn, the dialogic turn, and the biocultural turn [3], [4], [5], [6]. As we know, over the past fifty years many more theoretical 'turns' have emerged to address other aspects or a new direction in the field; including the digital turn [7].

Every day we face familiar and new situations that require us to make a choice about the direction one wants to take. But, if one does not know where one is coming from or needs to go, too many turns can lead to disorientation. These days, we also face the predicament of choosing whether to make a decision based on the actual reality of one's body-mind 'thinking' or to join the crowd and follow the virtual reality of 'smart' technology.

Resolving this dilemma may need an outlook as conveyed in an aphorism from the Serat Kala Tidha by Javanese poet-philosopher Ronggawarsita (circa 1860 translated in Errington [8]):

\section{To know oneself the troubled times}

is to know trouble in one's mind:

to go along with the insanity is unthinkable, yet if one does not, 
one finds no share,

and so starves at last.

Yet thus is God's will:

happy perhaps are those who forget themselves, happier still are those who are aware and careful. ${ }^{1}$

These wise words are commonly known by Indonesians born before the 1980s. But, what about the 'millennial generation'? How can they still have actual experiences of cultural practices and values in this time of increased use of new digital technologies? As I proposed in a book chapter [9] and earlier articles [10], [11], my sense is that activities which engage older and younger people together in arts learning is a way to support intergenerational dialogue for the transmission and transformation of traditional and new knowledge and skills.

\section{Place-BASED PRACTICE OF THE ARTS}

My second proposition is that a re-turn to place-based practice of the arts is a key for awakening the sensitivity of the body, heart, and mind in relation to others and to the natural and built environment. Why? Because the human capacity for knowing a place occurs by actually being in a place, experiencing it through our physical senses, and creative responses to it. So, let us consider some skills and values embedded in arts practice, particularly dance/movement arts (see Suryodarmo [12]; Butler [1]) such as:

- Beginning fresh again and again with attentiveness to the senses of sight, hearing, smell, touch, and taste as well as thought and kinesthetic experience;

- Opening awareness to the qualities of a place: the shapes, colors, textures, and sounds, layout and orientation of the land and structures or spaces, and the rhythm, dynamics, and movement of doings;

- Repetition for integrating body-mind experiences;

- Reconnecting with natural instincts and the capacity for tuning and adapting to changing conditions;

- Re-membering as in re-integrating lived experiences and also as in being a part of the community of humanity and of the wider natural world; and

- Transmitting and transforming past and current understandings by the creative process of artmaking.

In place-based practice of the arts, all of these processes are also in dialogue with the diversity of historical and current socio-cultural and aesthetic circumstances.

As the 3rd Social Sciences, Humanities and Education Conference took place in Java, I looked at A Book of Self Re-Education by the Dutch author Raden Ayou Jodjana [13] in which she compiled 'the results of life-long research’ with her husband, Yogyakarta-born movement artist Raden Mas Jodjana (1893-1972), and notes poignantly in Volume I: The Structure and Functions of the Human Body as an Instrument of Expression:

The whole body will then become receptive, and we will be attentive in every moment. Thus we start to live each moment with full attention. As life urges us to express ourselves, and to move, intentions and impulses mount from the treasure house of past experience, and we will know immediately what must be done in the moment. All we do and say will then take place, and manifest in perfect harmony. We will be linked to all outside forms, to persons, animals and plants even to all tools and objects that we touch.

\section{CONFIDENCE IN PRIORITIZING ART-MAKING AS A LIFELONG LEARNING PROCESS}

The good news is that the cultural dimension of life and creativity has been of primary importance in Indonesia for decades (see Soebadio [14]). The recent Undang-Undang Republik Indonesia nomor 5 tahun 2017 tentang Pemajuan Kebudayaan (Law of the Republic of Indonesia number 5 of the Year 2017 concerning Cultural Advancement) [15] also places culture as the foremost section for national development. This cultural policy encompasses the diversity of oral traditions, customary traditions, rites, traditional knowledge, traditional technologies, the arts, languages, traditional games, and traditional sports. Specifically, it recognizes art as 'individual, collective, or communal artistic expressions based on cultural heritage as well as the creativity of new works which manifest in various forms of activities and/or mediums ... such as performing arts, visual arts, literary arts, film, music, and media arts'. Moreover, it states that mainstreaming of culture is carried out through education to achieve the aim of cultural advancement.

In light of all that I have reflected on above, I believe that a re-turn to place-based practice of the arts is increasingly important for people of all ages in the twenty-first century in that it directly relates to the local character and conditions of each cultural environment. My hope is that this keynote paper can also encourage our confidence in prioritizing art-making as a lifelong learning process for the flourishing of cultural creativity.

\section{ACKNOWLEDGMENT}

Appreciation to the Rector of Universitas Udayana, Dean of the Fakultas Ilmu Budaya, and Chair of the Kajian Budaya Doctoral Program for the facilities and opportunities provided during my doctoral studies and current post as a volunteer Associate Professor. Gratitude to the founder of Padepokan Lemah Putih, Sharing Movement colleagues, cooperative members of Dharma Nature Time and all of the people who shared art, prayer, ideas, questions, dialogue, skills and materials that have made Sharing Art programs in Indonesian provinces and in other countries possible.

\footnotetext{
${ }^{1}$ amenangi jaman edan, ewuh aya ing pambudi, melu ngedan nora tahan, yen tan melu anglakoni, boya kedumen melik, kaliren wekasanipun, dilalah karsa Allah, begja-begjane kang lali, luwih begja kang eling klawan waspada.
} 


\section{REFERENCES}

[1] D. Butler, "Cultural heritage and the role of spatial-temporalkinesthetic knowledge through the arts" in Proceedings of 7th International Seminar on Nusantara Heritage. Kelantan: UMK Press, pp. 153-159. 2018.

[2] D. Butler, "Religiosity in Art inspired by Samuan Tiga and Tejakula, Bali: Unity in Diversity,” Ph.D. thesis, Universitas Udayana, Bali. 2011.

[3] C. Novack, "Looking at Movement as Culture". The Drama Review, XXXII, No. 4, Winter. 1988

[4] J.J. Fox, The Poetic Power of Place: Comparative Perspectives on Austronesian Ideas of Locality. Canberra: The Australian National University. 1997.

[5] D. Sklar, "Reprise: On Dance Ethnography". Dance Research Journal, Vol. 32, No. 1, pp. 70-77. 2000.

[6] UNESCO, Synergies between formal and non-formal education: an overview of good practices. Paris: UNESCO Education Sector. 2006.

[7] D. Kergel, et al (eds), The Digital Turn in Higher Education: International Perspectives on Learning and Teaching in a Changing World. Wiesbaden: Verlag für Sozialwissenschaften. 2018.

[8] R. N. Ronggawarsita, Serat Kala Tidha. Excerpt translated by J. Joseph Errington, 1989, in Alton L. Becker (ed.), Writing on the Tongue. Ann Arbor: The University of Michigan. 1860. pp. 95138.

[9] D. Butler, "Awakening Art and Dharma Nature Time: participatory approaches to interculture in cultural environments," in Embodied Lives: Reflections on the Influence of Suprapto Suryodarmo and Amerta Movement. Katya Bloom, Margit Galanter, and Sandra Reeve, eds. Dorset, UK: Triarchy Press. 2014. ch. 30.

[10] D. Butler, "Revitalizing Banjar for the Transformation of Traditional Cultural Values and Practices' in Proceedings of International Conference on Popular Culture and Cultural Values from the Perspective of Public Policy. Fakultas Ilmu Sosial dan Ilmu Politik, Universitas Ngurah Rai, Bali. 2017a.

[11] D. Butler, "Bridging Informal, Non-formal and Formal Educational Approaches to support the Arts, Cultural Heritage Diversity, and Social Cohesion" in Proceedings of 6th International Seminar on Nusantara Heritage. Institut Seni Indonesia-Denpasar. 2017b. pp. xviii-xxv.

[12] S. Suryodarmo, "Meditasi dalam Tari: 'Tari Meditasi?” in Seminar Nasional Seni Tari dalam Kehidupan Manusia. Surakarta: Institut Seni Indonesia. 2009.

[13] R. A. Jodjana, A Book of Self Re-education. Essex: L.N. Fowler. 1981.

[14] H. Soebadio, "Cultural policy in Indonesia". Based on annual reports of the Department of Education and Culture and material of the Centres and Directorates of the Directorate-General of Culture. Paris: UNESCO. 1985

[15] Republik Indonesia. "Undang-Undang Republik Indonesia nomor 5 tahun 2017 tentang Pemajuan Kebudayaan”, ratified by the Ministry of Law and Human Rights. Jakarta, 29 Mei. 2017. 